\title{
Walrus (Odobenus rosmarus) predation on adult thick-billed murres (Uria lomvia) at Coats Island, Nunavut, Canada
}

\author{
Mark L. Mallory, Kerry Woo, Anthony J. Gaston, \\ W. Eric Davies \& Pierre Mineau
}

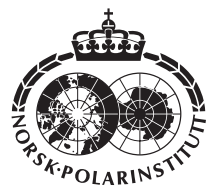

\begin{abstract}
Although the diet of walrus (Odobenus rosmarus) is considered varied, records of walrus consuming marine birds are rare in the published literature. In 2001 and 2002 we observed walrus foraging on adult thick-billed murres (Uria lomvia) at Coats Island in Nunavut, Canada. Approximately $46 \%$ of the attacks on murres were successful, and as many as 67 murres may have been killed in one day in August 2002. All soft parts of the murres were sucked out, with carcasses of only bones, feathers and skin left floating on the water. The extent to which predation on seabirds by walrus occurs across the eastern Arctic is unknown, but it could represent an important source of mortality for murres at some breeding colonies.
\end{abstract}

M. L. Mallory, Canadian Wildlife Service, Box 1714, Iqaluit, Nunavut, CanadaX0A 0H0, mark.mallory@ec. gc.ca; K. Woo, Environment Canada, 351 St. Joseph Blvd., Hull, Quebec, Canada K1A 0H3; A. J. Gaston \& P. Mineau, National Wildlife Research Centre, Carleton University, Raven Road, Ottawa, Ontario, Canada K1A 0H3; W. E. Davies, Dept. of Biological Sciences, Simon Fraser University, Burnaby, BC, Canada V5A 1 S6.

The walrus (Odobenus rosmarus) is a circumpolar pinniped that has a varied diet. Evidence from numerous studies indicates that both Pacific walrus (O. $r$. divergens Illiger) and Atlantic walrus (O. $r$. rosmarus Linneaus) are top predators in some trophic webs. While the majority of their diet consists of benthic invertebrates, particularly mollusks (Mansfield 1958; Loughrey 1959; Fay 1982; Fay et al. 1984; Fisher \& Stewart 1997), both traditional ecological knowledge and infrequent direct observation confirm that walrus also consume seals, fish and whales (Mansfield 1958; Fay 1982; Lowry \& Fay 1984), though in some of these instances walruses may have been foraging on carrion. Although it was initially suggested that feeding on higher level vertebrates represented aberrant behavior (Gray 1927; Vibe 1950), more recent investigation has demonstrated that it is a common feature of walrus feeding behaviour in both subspecies (Lowry \& Fay 1984; Muir et al. 1995).

We know little about possible foraging by walrus on marine birds. Fay et al. (1990) found a black guillemot (Cepphus grylle) in the stomach of a Pacific walrus, and they cited earlier, unconfirmed studies which suggested that walrus occasionally consume "birds". The only other published record of birds occurring in the diet of walrus was made by Donaldson et al. (1995), who watched walrus hunting and successfully capturing young thick-billed murres (Uria lomvia). None of the other large dietary studies (above) have made similar observations. Here we report on the hunting behaviour, attack and success rates, and food processing behaviour of Atlantic walrus we observed hunting adult thick-billed 


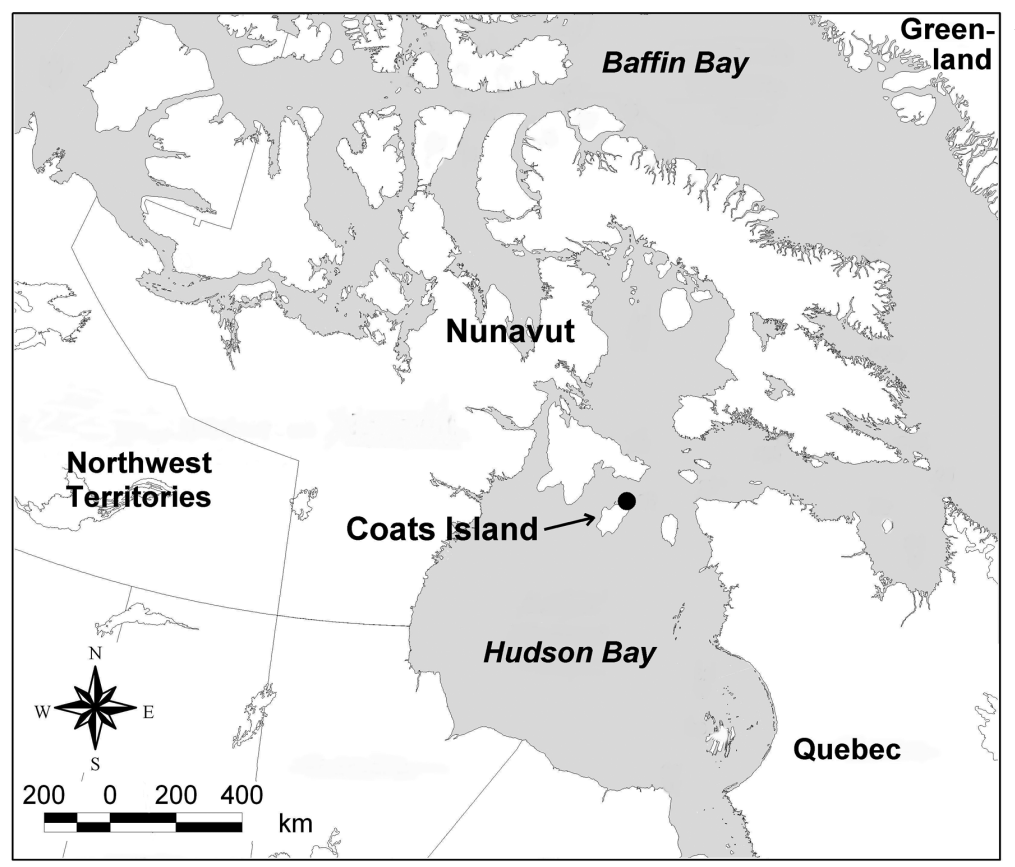

Fig. 1. The location of Coats Island, Nunavut, Canada.

murres in the eastern Arctic region of Canada.

\section{Methods}

We recorded walrus hunting thick-billed murres during work on a long-term study of murre reproductive ecology at Coats Island, northern Hudson Bay, Nunavut, Canada $\left(62^{\circ} 57^{\prime} \mathrm{N}, 82^{\circ} \mathrm{W}\right.$; Fig. 1; Gaston et al. 1993). The diet of walrus in this part of Hudson Bay has been investigated previously (Mansfield 1958), but remains of seabirds were not reported. Our observations of walrus were made from atop the murre colony on an $85 \mathrm{~m}$ cliff north-west of Cape Pembroke, from where observations of beluga whales (Delphinapterus leucas) also have been reported (Gaston 2000).

\section{Results}

On 15 August 2001, we observed a young male walrus foraging in the cove beside the murre colony at Coats Island. Weather conditions were sunny and the water had only a small surface chop. Presumably, the walrus had already been feeding when we initiated observations, as there were several murre carcasses floating on the water.
During the predation events, the walrus bobbed its head out of the water, apparently scanning for flocks, and then began to approach the bird(s), often just below the surface of the water. Once it was within a few metres it would fully submerge, swimming rapidly (in comparison with other walrus not engaged in murre predation) and then burst through the surface immediately adjacent to a murre, grasping it in its mouth. After a successful kill, the walrus would often roll onto its side or back and process the bird while holding it between its flippers.

In the two hours of observations, we recorded 35 attacks (defined as breaking the surface near a murre), 16 of which were successful (Table 1). The mean duration between attacks was $2.6 \pm 2.0$ $\mathrm{SD} \min (\mathrm{N}=30$, range $1-8)$, with $6.5 \pm 4.0 \mathrm{~min}$ $(\mathrm{N}=15$, range 1-18) elapsing between successful attacks. The walrus varied its handling time for each bird, averaging $4.7 \pm 3.0 \min (\mathrm{N}=6$, range $1-10)$.

On 8 August 2002, we made similar observations to those in 2001. At 07:15, we noticed a walrus feeding in the cove. Weather conditions were foggy and cool, but the water surface was calm. A recent storm had dislodged much kelp, which floated just below the water surface. The walrus patrolled back and forth along the foot of the colony cliffs. There were several murre car- 
casses floating on the surface, indicating that the walrus had probably been feeding prior to our observations. Between 07:15 and 08:00, eight murres were captured, for an average capture rate of 5.6 min per bird, similar to that in 2001 . The technique used was also similar to the previous year, with two minor differences. First, the walrus appeared to surface immediately beside a floating bird and bite off a piece of the murre during the attack. Second, the prey was consumed principally underwater, not above the surface with the walrus rolled over on its back. The walrus appeared to be most successful in hunting murres that were turned away from its approach and occupied with preening. Many murres did see the walrus and were observed taking flight before it had a chance to strike.

At 14:50 a walrus (presumably the same individual) was observed feeding on murres, with seven attacks observed averaging $3.1 \pm 1.3 \mathrm{~min}$ $(\mathrm{N}=5$, range 1.9-4.7) between each, similar to the frequency in 2001 (Table 1). We noted that the walrus took five to eight strong breaths between hunting attempts, and then submerged and approached the birds. Four murres were captured before the walrus departed at 15:35. We saw 11 murre carcasses floating in sight of the observation blind at this time.

In both years, the walrus did not swallow the birds whole nor did it appear to do much chewing. Instead, it ripped open part of the bird during the initial attack, sucked out the soft contents, and left behind only hard parts and the skin turned inside out with feathers still attached. We checked the corpses of two murres in 2002, and these retained the wings, skin and feathers, ribs and sternum, backbone, feet, neck and head (with the skin pulled over), but all soft internal tissues had been removed.

\section{Discussion}

Our observations confirm that walrus can successfully capture adult thick-billed murres. Indeed, surprisingly high numbers of adults were probably eaten each day. Previously, walrus were seen attempting to take adult murres twice near the Coats Island colony, in August 1991 and in July 1994, when two animals were involved (Donaldson et al. 1995; D. J. Andrews \& K. Kampp, unpubl. data). However, no successful predation on adult murres was recorded. Donaldson et al. (1995) also reported that the walrus seen in August 1991 ate two flightless young murres. Because Donaldson et al. (1995) had spent many field seasons at the site and had rarely recorded this interaction, they suggested that murres do not make up a significant proportion of the walrus diet. While we agree with this contention, we note that the walrus in 2002 could have consumed 67 murres between the start and end of our observations ( $8.3 \mathrm{~h}$ at $8 \mathrm{birds} / \mathrm{h}$ ). The possible depredation of more than 50 murres per day, even intermittently during the breeding season, means that walrus may be an important albeit occasional predator on adult murres at this site. Walrus are more abundant at this murre colony than at any other colony in the Canadian Arctic (A. J. Gaston, unpubl. data), so the extent to which walrus predation occurs on murres elsewhere is unknown. Across all murre colonies, Arctic foxes (Alopex lagopus) and glaucous gulls (Larus hyperboreus) are presumably much more important predators, consuming numerous eggs and chicks (Gaston \& Hipfner 2000).

Thick-billed murres often fly from the breeding cliff and alight on the water below the colony to bathe and preen prior to departing on a foraging trip (Gaston \& Hipfner 2000). In addition, many pre-breeding birds gather there to socialize, especially during the latter part of the breeding season (mid-July to mid-August). Birds bathing, preen-

Table 1. Summary values of observation times and feeding behaviours of walruses feeding on seabirds at Coats Island, 2001-02.

\begin{tabular}{cccccc}
\hline Walrus & $\begin{array}{c}\text { Date and time } \\
\text { (EDT) }\end{array}$ & $\begin{array}{c}\text { Observation } \\
\text { duration }(\mathrm{h})\end{array}$ & $\begin{array}{c}\text { Attack rate } \\
\text { (birds/h) }\end{array}$ & $\begin{array}{c}\text { Capture rate } \\
\text { (birds/h) }\end{array}$ & $\begin{array}{c}\text { Handling } \\
\text { duration }(\mathrm{min})\end{array}$ \\
\hline 1 & $\begin{array}{c}\text { 15 Aug. 2001 } \\
\text { 11:20-13:20 }\end{array}$ & 2 & 17.5 & 8.0 & 4.7 \\
2 & $\begin{array}{c}\text { 8 Aug. 2002 } \\
\text { 07:15-08:00 }\end{array}$ & 0.75 & - & 10.7 & - \\
& $14: 50-15: 35$ & 0.75 & 9.3 & 5.3 & - \\
\hline
\end{tabular}


ing and socializing within $200 \mathrm{~m}$ of the colony cliff were the targets of the observed walrus predation and the prey therefore may have included both breeders and non-breeders.

Walrus appear to eat only the soft internal tissues of murres, despite possessing the teeth to effectively masticate bird bones (Mansfield 1958). Walrus may ingest their bivalve prey whole (Fay et al. 1984), but those that have consumed seals appear to eat the skin, blubber and some muscle, leaving much of the skeleton (Lowry \& Fay 1984). When preying on birds and perhaps on seals, walrus appear to leave the energy-deficient body tissues behind.

The hunting method used by walruses was consistent with those reported by Donaldson et al. (1995), and was also similar to the approach used by polar bears (Ursus maritimus) preying on murres. How many walrus use this technique is unknown and it is unclear how commonly walrus consume seabirds. The murre colony at Coats Island has large, established walrus haulouts at Khaluktuk Island (near Cape Prefontaine) and Bencas Island to the west and near Cape Pembroke to the east. Murres are scattered across the sea for several kilometres from the colony, and walrus move through this area almost daily (A. J. Gaston, unpubl. data). Despite this, we have only two observations of walrus successfully preying on murres. Hence, although much predation could go unnoticed, it seems unlikely that this activity is widespread in the walrus population and may be the work of one or two specialist animals. However, it is worth noting that, because these walrus consumed only the soft parts of the birds (like blubber and skin consumed on seals; Lowry \& Fay 1984), which are probably digested relatively rapidly, evidence of predation on birds might not show up as easily in dietary studies as the hard parts of mollusks. Isotopic and contaminant approaches suggest that seals form a higher proportion of the diet in some regions than previously suspected based on traditional dietary analyses (Muir et al. 1995).

Our observations highlight two important aspects of the trophic web in this part of northern Hudson Bay. First, walrus can be effective predators of seabirds, including those capable of flight, and thus they may fill an analogous niche to some pinnipeds of the Antarctic Ocean (e.g. leopard seal [Hydrurga leptonyx]; Reidman 1990). Second, predation by walrus could represent an important, although intermittent, source of mortality for murres at some breeding colonies in the eastern Canadian Arctic. The extent to which walrus may prey on other types of seabirds (eiders, fulmars and gulls) merits closer attention.

Acknowledgements.-Thanks to Josiah Nakoolak and Carolyn Saunders who assisted in some of these observations. Financial and logistic support was provided by the Canadian Wildlife Service and the Polar Continental Shelf Project.

\section{References}

Donaldson, G. M., Chapdelaine, G. \& Andrews, J. D. 1995: Predation of thick-billed murres, Uria lomvia, at two breeding colonies by polar bears, Ursus maritimus, and walruses, Odobenus rosmarus. Can. Field-Nat. 109, 112-114.

Fay, F. H. 1982: Ecology and biology of the Pacific walrus, Odobenus rosmarus divergens Illiger. North Am. Fauna 74.

Fay, F. H., Bukhtiyarov, Y. A., Stoker, S. W. \& Shultz, L. M. 1984: Foods of the Pacific walrus in winter and spring in the Bering Sea. NOAA Tech. Rep. NMFS 12. US Department of Commerce.

Fay, F. H., Sease, J. L. \& Merrick, R. L. 1990: Predation on a ringed seal, Phoca hispida, and a black guillemot, Cepphus grylle, by a Pacific walrus, Odobenus rosmarus divergens. Mar. Mamm. Sci. 6, 348-350.

Fisher, K. I. \& Stewart, R. E. A. 1997: Summer foods of Atlantic walrus, Odobenus rosmarus rosmarus, in northern Foxe Basin, Northwest Territories. Can. J. Zool. 75, 1166-1175.

Gaston, A. J. 2000: Occurrence of beluga, Delphinapterus leucas, in summer off northeastern Coats Island, Northwest Territories. Can. Field-Nat. 114, 236-240.

Gaston, A. J., de Forest, L. N., Gilchrist, H. G. \& Nettleship, D. N. 1993: Monitoring thick-billed murre populations at colonies in northern Hudson Bay, 1972-92. Canadian Wildlife Service Occasional Paper 80. Ottawa.

Gaston, A. J. \& Hipfner, J. M. 2000: Thick-billed murre (Uria lomvia). The birds of North America (A. Poole and F. Gill eds.) 497. Philadelphia: The Birds of North America Inc.

Gray, R. W. 1927. The walrus. Nature (Lond.) 11, 923.

Loughrey, A. G. 1959: Preliminary investigation of the Atlantic walrus, Odobenus rosmarus rosmarus (Linnaeus). Canadian Wildlife Service Wildlife Management Bulletin 14, Ser. 1.

Lowry, L. F. \& Fay, F. H. 1984: Seal eating by walruses in the Bering and Chukchi seas. Polar Biol. 3, 11-18.

Mansfield, A. W. 1958: The biology of the Atlantic walrus, Odobenus rosmarus rosmarus (Linnaeus) in the eastern Canadian Arctic. Fisheries Research Board of Canada Manuscript Report Series (Biology) 653

Muir, D. C. G., Segstro, M. D., Hobson, K. A., Ford, C. A., Stewart, R. E. A. \& Olpinski, S. 1995: Can seal eating explain elevated levels of PCBs and organochlorine pesticides in walrus blubber from eastern Hudson Bay (Canada)? Environ. Pollut. 90, 335-348.

Reidman, M. 1990: The pinnipeds. Seals, sea lions and walruses. Berkely: University of California Press.

Vibe, C. 1950: The marine mammals and the marine fauna in the Thule district (northwest Greenland) with observations on ice conditions in 1939-41. Medd. Grønl. 150. 